\title{
Review of the distribution and conservation status of the terrestrial reptiles of the Cape Verde Islands
}

\author{
Raquel Vasconcelos, José Carlos Brito, Salvador Carranza and \\ D. JAMES HARRIS
}

\begin{abstract}
Cape Verde has a higher number of reptile taxa and endemics than any of the five archipelagos in the Macaronesian region. Mapping the precise distributions and assessing the conservation status of reptiles is the first step towards effective conservation. Presence/absence and abundance data were gathered from extensive fieldwork and post-1980 literature. Evaluation of conservation status was considered at specific and subspecific levels, following IUCN Red List criteria and using RAMAS. Fieldwork confirmed the occurrence of 34 of 37 previously recorded taxa (31 native, three exotic). One taxon continues to be considered Extinct. Three broad distribution and rarity patterns were identified: widespread and abundant taxa occurring on $\geq 2$ islands/islets, widespread or abundant taxa restricted to one island, and rare or limited range taxa occurring on small areas of islands or islets. More than a third of taxa have areas of occupancy $<20 \mathrm{~km}^{2}$ and extents of occurrence $<100 \mathrm{~km}^{2}$. Geckos are rarer than skinks because of their high habitat specialization, with $58 \%$ occurring on only one island/islet. About half of all taxa are potentially threatened, twice the proportion of those in the Canary Islands, a difference that could be explained by the smaller area and greater aridity of the Cape Verde islands. The criterion used for most threat categorizations is geographical range, and the most pervasive threats are natural disasters, intrinsic factors of the species and introduced species. The importance of applying conservation status at the subspecific level to island endemics is emphasized. Several conservation measures are proposed, including optimized design of protected areas.
\end{abstract}

Keywords Atlas, Chioninia, endemics, Hemidactylus, introductions, Macaronesia, Red List, Tarentola

\footnotetext{
RAQUEL VASCONCELOS (Corresponding author), Centro de Investigação em Biodiversidade e Recursos Genéticos da Universidade do Porto (CIBIO-UP), Campus Agrário de Vairão, R. Padre Armando Quintas, 4485-661 Vairão, Portugal, and Institut de Biologia Evolutiva (IBE), Consejo Superior de Investigaciones Científicas-Universitat Pompeu Fabra (CSIC-UPF), Passeig Marítim de la Barceloneta, 37-49, E-08003 Barcelona, Spain.

E-mail raquel.vasconcelos@cibio.up.pt

José Carlos Brito and D. James Harris Centro de Investigação em Biodiversidade e Recursos Genéticos da Universidade do Porto (CIBIO-UP), Vairão, Portugal, and Departamento de Biologia, Faculdade de Ciências da Universidade do Porto, Porto, Portugal

Salvador Carranza Institut de Biologia Evolutiva (IBE), Consejo Superior de Investigaciones Científicas-Universitat Pompeu Fabra (CSIC-UPF), Barcelona, Spain

Received 21 March 2011. Revision requested 2 June 2011.

Accepted 27 July 2011.
}

This paper contains supplementary material that can be found online at http://journals.cambridge.org

\section{Introduction}

B iodiversity loss is one of the top issues of the 21st century. Species with small range size and low gene flow are of particular concern as they have increased probability of extinction by chance alone (Pullin, 2002). For this reason, island populations have a higher risk of extinction than mainland populations (Frankham, 1997). Moreover, even though islands usually have a low number of species, the number of endemics is generally high (Kier et al., 2009), as is their vulnerability to the introduction of exotic species (Case et al., 1992). Thus, it is crucial to increase knowledge about native biodiversity in remote areas such as oceanic islands where species are particularly prone to extinction. One way of fulfilling this goal begins with the production of distribution atlases and updated Red Lists, as these are tools for conservation planning.

The Cape Verde Islands, an oceanic archipelago, lack detailed information on the distribution of biodiversity. Although there are preliminary inventories of the flora (Paiva, 1995), avifauna (Naurois, 1994; Hazevoet, 1995; Clarke, 2006) and herpetofauna (Schleich, 1987), there are no distribution atlases for terrestrial groups. There are no endemic mammals or amphibians. Intra-island distribution data for birds are being collected but accurate distribution data for reptiles are lacking. All native reptiles are endemics and the archipelago has the highest number of endemic reptile taxa in Macaronesia (Schleich, 1987; Pleguezuelos et al., 2002; López-Jurado et al., 2005; Oliveira et al., 2005), within three genera: Hemidactylus (Gekkonidae), Tarentola (Phyllodactylidae) and Chioninia (Scincidae; = Mabuya and Macroscincus; Miralles et al., 2010).

After the discovery of this oceanic archipelago by the Portuguese in 1460 several surveys on the fauna of Cape Verde were conducted, leading to the first studies of the taxonomy, systematics and morphology of the Cape Verdean herpetofauna in the 19th century. In the 2oth century a preliminary assessment of the reptiles listed 10 endemic terrestrial species (including 23 taxa), and reviewed their distributions at a coarse inter-island scale (Schleich, 1987). Later, taxonomic revisions made by Joger (1993), based on morphological analyses, increased to 12 and 26 the number of species and taxa, respectively. These data were 


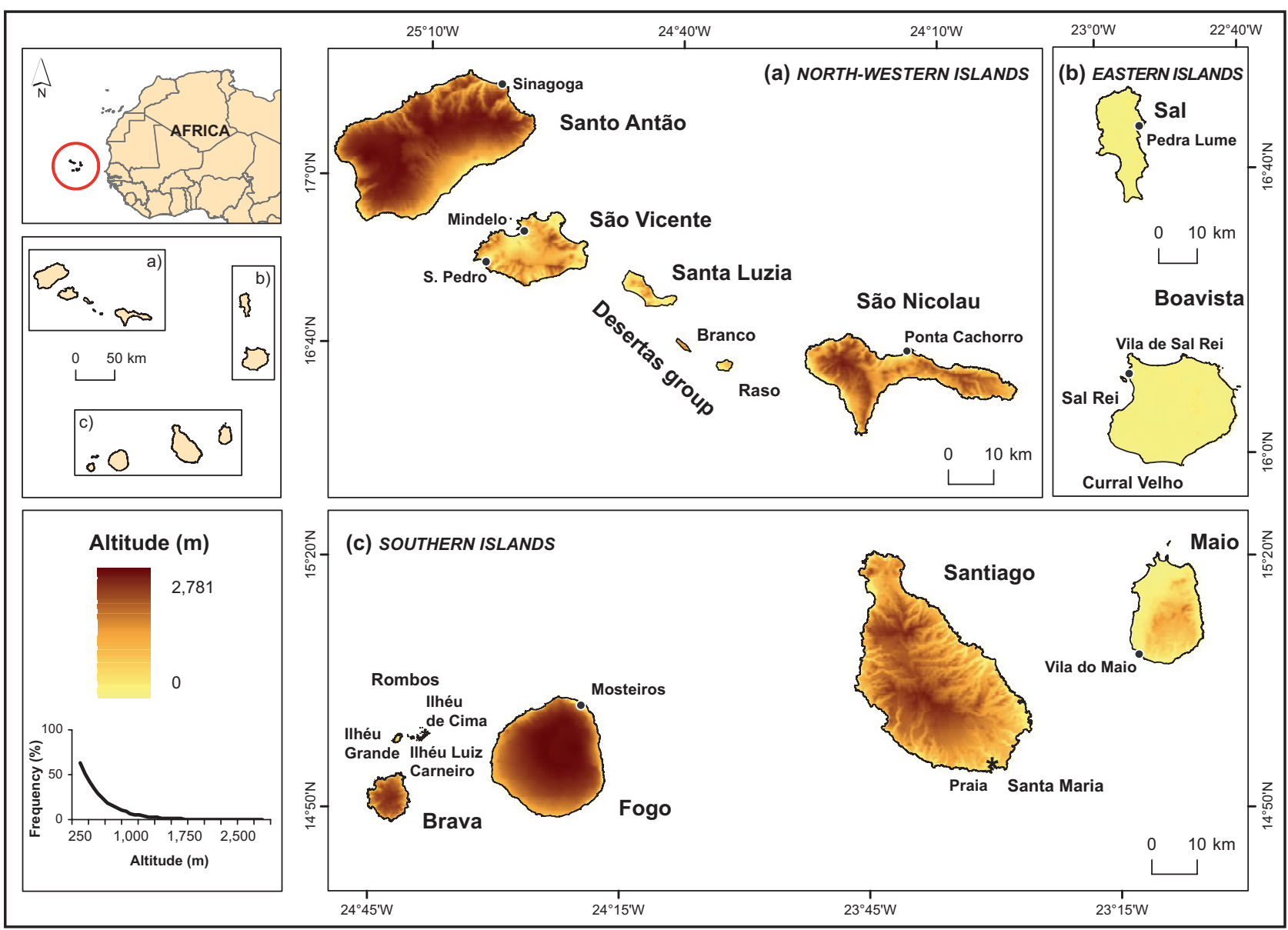

FIG. 1 The Cape Verde Islands, including altitudinal variation, and place names mentioned in the text.

compared with the now outdated (pre-2001) IUCN and German National List criteria to produce the first Red List for Cape Verde (Leyens \& Lobin, 1996). The assessment considered $25 \%$ of the terrestrial reptiles to be Extinct or threatened (Schleich, 1996), prompting the promulgation of a law for the protection of plant and animal species. This law considered Hemidactylus bouvieri razoensis Gruber \& Schleich (1982) as Critically Endangered; Tarentola gigas brancoensis Schleich (1984) and Tarentola gigas gigas (Bocage, 1875) as Endangered; Hemidactylus bouvieri bouvieri (Bocourt, 1870) as Rare and Tarentola rudis (Boulenger, 1906) and Chioninia (=Mabuya) vaillanti (Boulenger, 1887) as Undetermined (Anonymous, 2002).

Genetic studies conducted after 2000 by Brehm et al. (2001), Brown et al. (2001), Carranza et al. (2000, 2001, 2002), Carranza \& Arnold $(2003,2006)$ and Jesus et al. $(2001,2002)$ for phylogeographical purposes indicated the need for a systematic revision of the reptiles of Cape Verde. An extensive survey of Cape Verde has been carried out since 2006, collecting genetic and morphological data, to review the systematics of endemic reptiles (Arnold et al., 2008; Miralles et al., 2010; Vasconcelos et al., 2010, 2012b). These studies have increased to 22 the number of recognized endemic reptile species, with 31 taxa. The significant taxonomic revisions, naming previously unnamed populations and describing three new species and three new subspecies, increased the number of species by $83 \%$ and the number of taxa by $19 \%$ compared to the previous assessment (Schleich, 1996), and indicated the need to revise the distribution maps of all taxa and assess their conservation status using current IUCN criteria (IUCN Standards and Petitions Subcommittee, 2010).

The objectives of this study are to provide distribution data at an intra-island scale and to assess the conservation status of the endemic reptiles of Cape Verde. The fulfilling of these two goals will provide guidance for future management and conservation efforts.

\section{Study area}

The Cape Verde Islands belong to the biogeographical region of Macaronesia in the Atlantic Ocean (Fig. 1). They form a volcanic archipelago comprising 10 main islands plus several islets, with a total area of $4,067 \mathrm{~km}^{2}$. Island size varies from the 1,004 $\mathrm{km}^{2}$ Santiago to the $6 \mathrm{~km}^{2}$ Raso. The age of 
the islands is 2.6-26 million years, with islands closer to the mainland being the oldest, and consequently the flattest (Torres et al., 2002; Duprat et al., 2007).

The topography of Cape Verde ranges from plains to high mountains, reaching almost 3,000 $\mathrm{m}$ on the summit of the active volcano of Fogo. The elevation, steepness and orientation of mountains influence the amount of precipitation that each island receives. Cape Verde is situated just north of the Intertropical Convergence Zone and has a tropical dry climate with a long dry season, frequent long droughts, and an irregular short wet season from July to September (Duarte \& Romeiras, 2009). Mean annual temperature is relatively constant $\left(22^{\circ} \mathrm{C}\right)$ because of the moderating influence of the ocean. Annual precipitation is low $(<250 \mathrm{~mm})$ and highly variable both spatially and temporally (Hijmans et al., 2005) and there are almost no permanent water courses.

\section{Methods}

\section{Sampling}

The 10 islands were surveyed over 2006-2008 during the dry season, from mid May to mid July. Sampling stations (Appendix 1) were randomly chosen and stratified according to habitat availability, based on agro-ecological and vegetation zoning maps (adapted from Diniz \& Matos, 1986, 1987, 1988a,b, 1993, 1994, 1999a,b,c; Appendix 2), with the number of stations per habitat proportional to habitat area. Using this approach most of the variability between and within each habitat, in altitude, topography, climate and geographical position, was encompassed by the sampling stations. The sampled area, 440 stations of $1 \times 1 \mathrm{~km}^{2}$, corresponds to c. $11 \%$ of the country's area. Each station was sampled only by day (because of logistic constraints), along transects, for 35 minutes on average (5-120 minutes, according to the difficulty of the terrain), by two observers walking parallel to each other, totalling nearly 264 hours of sampling. Presence/absence and abundance data of taxa (no. of individuals observed or per $\mathrm{km}^{2}$ ) were recorded. Abundance data were taken as an indicator of the order of magnitude of the number of mature individuals.

\section{Presence data}

A total of 2,139 presence observations were collected from three sources: (1) 1,375 from fieldwork, consisting of indirect evidence (skins, eggs or skeletons) or direct captures of the animals (released afterwards), (2) 610 from the literature, and (3) 154 from GenBank. Total presence data (N) corresponds to the total data collected from the three sources. The geographical coordinates of fieldwork observations were recorded with a global positioning system.
Coordinates from literature records (Duméril \& Bibron, 1839; Gray, 1845; Bocourt, 1870; Bocage, 1873, 1875, 1896, 1897 , 1902; O'Shaughnessy, 1874; Vaillant, 1882; Boulenger, 1885, 1887, 1906; Peracca, 1891; Orlandi, 1894; Serpa-Pinto, 1896; Angel, 1935, 1937; Loveridge, 1947; Dekeyser \& Villiers, 1951; Mertens, 1955; Greer, 1976; Schleich, 1980, 1982a,b, 1984, 1987, 1996; Gruber \& Schleich, 1982; Schleich \& Wutke, 1983; Joger, 1984a,b, 1993; Brygoo, 1985, 1990; Pinheiro, 1990; Hazevoet, 1995; Mateo et al., 1997, 2005, 2009; López-Jurado et al., 1998, 1999, 2005; Andreone, 2000; Carranza et al., 2000, 2001, 2002; Brehm et al., 2001; Brown et al., 2001; Jesus et al., 2001, 2002, 2005; Andreone \& Guarino, 2003; Carranza \& Arnold, 2003, 2006; González \& LópezJurado, 2004; Chadwick \& Slater, 2005; Frazen \& Glaw, 2007; Köhler \& Güsten, 2007; Köhler et al., 2007a, b; Arnold et al., 2008) and GenBank data were determined from topographical maps $(1: 25,000)$. All coordinates were recorded or determined on the WGS84 datum and mapped using ArcGIS v. 9.3 (ESRI, Redlands, USA).

When an endemic taxon was found outside its previously known range within the archipelago it was considered a probable recent anthropogenic introduction if it was genetically close to individuals found on the island of origin of the taxon (Miralles et al., 2010; Vasconcelos et al., 2010) and if, after extensive sampling, only a small number of individuals was found mainly on the coast rather than inland.

\section{Conservation status}

Conservation status was evaluated at specific and subspecific levels, following the methodology and criteria of the IUCN Red List guidelines (IUCN Standards and Petitions Subcommittee, 2010). A taxon was considered threatened when it qualified as Vulnerable (VU), Endangered (EN) or Critically Endangered (CR), according to the criteria of population reduction $(\mathrm{A})$, geographical range $(\mathrm{B})$, small population size and decline $(\mathrm{C})$, or very small or restricted population (D; IUCN Standards and Petitions Subcommittee, 2010). Non-indigenous and fossil taxa were listed as Not Evaluated (NE).

Criteria were applied with RAMAS Red List v. 2.0 (Akçakaya \& Ferson, 2001). Parameters for categorization were (1) population number, estimated from the number of mature individuals using abundance data, (2) population reduction, estimated from subfossil and published data, (3) area of occupancy (AOO), calculated from the number of occupied cells $\times$ area of an individual cell $\left(1 \times 1 \mathrm{~km}^{2}\right)$ considering only observations after 1980, (4) extent of occurrence (EOO), estimated by the minimum convex polygon method, which determines the area contained within the shortest continuous imaginary boundary that can be drawn to encompass all the occurrences of a taxon 
(calculations made with Hawth's Tools extension for ArcGIS, Beyer, 2004), and (5) population fragmentation, based on the number of locations (corresponding to the number of habitats where occurrence was registered; see Sampling above and Appendix 2), and number of subpopulations (quantified by the number of islands or islets of occurrence of a taxon). The only exceptions to (5) were applied to Tarentola darwini and Chioninia spinalis santiagoensis, which each presented two evolutionarily significant units on the same island and thus the number of subpopulations did not coincide with the number of islands or islets of their occurrence (Miralles et al., 2010; Vasconcelos, et al. 2010).

Taxa were considered to have a restricted range (RR) if $\mathrm{AOO}$ was $<20 \mathrm{~km}^{2}$ or the number of locations of occurrence was $\leq 5$ (Akçakaya \& Ferson, 2001). An exception was made for Chioninia spinalis spinalis, which was not considered to be RR because, even though its value of AOO was $<20 \mathrm{~km}^{2}$, this was assumed to be the result of an underestimation of presences. Sampling occurred during the dry season and this, together with the steep slopes of Fogo Island, made detection difficult. Major threats for each taxon were assessed using a standardized list (IUCN, 2010; Appendix 3) implemented in RAMAS and were evaluated based on information gathered from fieldwork and published data.

\section{Results}

\section{Presence data}

During the fieldwork we made 50 observations of exotic taxa and 1,325 of native taxa, and the literature and GenBank data together contributed 21 and 743 observations of exotic and native taxa, respectively. A total of 38 taxa were recorded, of which 31 were native (not counting fossil species) and six exotic (Table 1). Of these, only 34 taxa (31 native and three exotic) were confirmed by fieldwork. The distributions of observations are given in Appendices 4-7. Detailed information about doubtful and historical records is given in Appendix 8.

Three exotic reptile species were confirmed to be present (Appendix 4). The most abundant and widespread species is Hemidactylus angulatus, which occurs on at least six islands and one islet. The most recent introduction recorded is Agama agama on Santo Antão, São Vicente and Santiago. Fieldwork produced first records of Hemidactylus mercatorius (referred as Hemidactylus mabouia by previous authors) on Santo Antão and Brava and confirmed the occurrence of the species on São Vicente.

Fieldwork confirmed the following introductions of endemic taxa: (1) Chioninia delalandii in Vila do Maio, Maio (originally present on all other southern islands) and
Mindelo, São Vicente, (2) Tarentola maioensis (originally from Maio) at Ponta Cachorro, São Nicolau, and (3) Tarentola substituta (originally from São Vicente) in Sinagoga, Santo Antão (Table 1).

Of the 31 endemic taxa five belong to the genus Hemidactylus, 14 to Tarentola and 12 to Chioninia (Table 1). Unsuccessful searches were conducted for Chioninia (=Macroscincus) coctei by three observers on Santa Luzia Island during 5 days. Three broad distribution and rarity patterns were identified for extant taxa: (1) widespread and abundant taxa, occurring on two or more islands or one island and distant islets (e.g. Hemidactylus boavistensis, Tarentola raziana and C. delalandii), (2) widespread or abundant taxa, restricted to one island and its neighbouring islets (Tarentola boavistensis, T. darwini and Chioninia spinalis maioensis), and (3) rare or limited range taxa, occurring on an islet or a small part of an island (H. bouvieri spp., Hemidactylus lopezjuradoi, Tarentola bocagei, T. gigas spp., T. rudis, Tarentola protogigas protogigas and C. vaillanti spp.; Table 1; Appendices 5-7).

The native $C$. delalandii and $T$. darwini have the largest EOO and AOO, T. g. brancoensis and T. g. gigas have the smallest EOO, and $H$. lopezjuradoi and $H$. b. bouvieri the smallest AOO (Table 1, Appendices 5-7). C. delalandii is the taxon with the highest number of confirmed subpopulations, followed by $H$. bouvieri, Chioninia stangeri and H. boavistensis. About $40 \%$ of the reptile taxa have an AOO $<20 \mathrm{~km}^{2}$, geckos 1.5 times more than skinks ( $47 \%$ of geckos vs $33 \%$ of skinks). About a third $(36 \%)$ of all taxa have an EOO $<100 \mathrm{~km}^{2}$, especially geckos $(53 \%$ of geckos vs $8 \%$ of skinks).

About $30 \%$ of the taxa occur in $<5$ locations, and $58 \%$ occur on only one island or islet, with a similar pattern for geckos and skinks (Table 1). Thirteen of the reptile taxa $(42 \%)$ have a restricted range, with higher values for geckos than for skinks.

Most ( $71 \%)$ of the taxa were recorded below $250 \mathrm{~m}$ altitude but $24 \%$ occur at 250-1,000 m (Appendices 4-7). Examples of taxa occurring at altitudes above 1,000 $\mathrm{m}$ are C. delalandii, Chioninia fogoensis, C. s. spinalis, Chioninia vaillanti vaillanti and Tarentola caboverdiana.

\section{Conservation status}

A summary of the current conservation status of the endemic taxa is presented in Table 1. About half of the reptiles are threatened (Table 1). One taxon is categorized as Extinct, c. $16 \%$ of the taxa as Critically Endangered or Endangered, and $19 \%$ as Vulnerable. Geckos have twice $(63 \%)$ the percentage of threatened taxa as skinks (33\%), with $80 \%$ of Hemidactylus categorized as Critically Endangered.

The most frequently used criterion for categorization of threat was geographical range $(\mathrm{B} ; 56 \%)$. The most pervasive 
threats were natural disasters $(74 \%)$, specifically droughts and volcanoes, and intrinsic factors of taxa (42\%), specifically restricted range and low densities (Table 1 ; Appendix 3).

\section{Discussion}

This research presents for the first time accurate withinisland information on the distribution of the terrestrial reptiles of Cape Verde, including newly described and revised taxa, and a revised conservation assessment using the IUCN criteria for all taxa, many of them previously categorized as Data Deficient or Undetermined (T. boavistensis, T. substituta, T. rudis and C. vaillanti; Schleich, 1996).

The considerable extent of occurrence of two introduced and invasive Hemidactylus species, $H$. angulatus and $H$. mercatorius, is alarming, with $H$. angulatus widespread on Santiago and Boavista Islands, and H. mercatorius having spread to other islands. It is known that introduced Hemidactylus can cause catastrophic declines and extinctions of endemic geckos, as $\mathrm{H}$. frenatus did with Nactus species on the Mascarene Islands (Cole et al., 2005). In addition, island invasions can be fast and human-mediated and recent reptile extinctions have occurred exclusively on islands (Case et al., 1992). Given that some endemic forms, such as $H$. bouvieri and $H$. lopezjuradoi, Critically Endangered, and that $H$. angulatus is probably already displacing some populations of the endemic $H$. boavistensis (López-Jurado et al., 1999) information regarding the extent of this threat is vital and monitoring is required. New taxa are being introduced in the archipelago, such as A. agama on Santo Antão (Vasconcelos et al., 2009), and recently also on São Vicente (E. Lopes, B. Martins \& R. Vasconcelos, pers. obs) and Santiago (A. Rendall, G. Semedo, J. Semedo \& R. Vasconcelos, pers. obs), and measures are required to prevent the entry of further exotic taxa to this vulnerable ecosystem.

Our extensive sampling did not confirm the introduction of the endemics T. nicolauensis to Mindelo, São Vicente (Jesus et al., 2002) or C. delalandii to Sal Rei, Boavista (Schleich, 1987). This may be because of low population sizes, or the extinction of the populations, as suggested by López-Jurado et al. (1999) in the latter case. However, our sampling detected new introductions of T. substituta on Santo Antão and C. delalandii on São Vicente.

Our searches and those of previous expeditions since 1912 for the native Chioninia coctei have been unsuccessful. Some authors considered $C$. coctei to be Extinct by the beginning or second half of the 2oth century (Chevalier, 1935; Schleich, 1982a, 1984; Hazevoet, 1995) and it has been categorized Extinct by IUCN since 1986 (Schleich, 1996). Extinction was because of over-collection, prolonged droughts and predation by feral cats (Andreone, 2000). Bocage (1896) also noted the unsustainable collection of specimens by naturalists. Nevertheless, there is still the possibility that a few individuals survive on Santa Luzia or other islands or islets (Appendix 8). Several threatened Cape Verde taxa have restricted ranges, with particular habitat associations or a low number of records (Appendix 9) and may be at risk of extinction.

The major threats to the biodiversity of this archipelago are habitat fragmentation for agriculture and cattle, introduced species, direct exploitation by hunting, collection and logging (Leyens \& Lobin, 1996), and severe droughts (MAAP-DGA, 2004). For reptiles, the major threats are natural disasters such as droughts and volcanic activity, intrinsic factors of the species such as low densities and restricted ranges, and exotic species (Appendix 3). The endemic Hemidactylus and T. p. protogigas are potentially the most threatened taxa.

IUCN criteria were applied at the subspecific level as Cape Verde is an insular system and reptile populations face conservation problems that need to be addressed at that level. For example, T. protogigas is Critically Endangered on Fogo because of supposed continuing decline and restricted range but on Brava and Rombos the species is Vulnerable.

The frequent classification of threatened taxa based on the IUCN Red List criterion B, related to geographical range, is a common pattern in reptile assessments (Pleguezuelos et al., 2002, 2010; Oliveira et al., 2005), associated with the lack of data concerning population trends and probability of extinction related to criteria $\mathrm{A}$ and $\mathrm{E}$, respectively. Use of criterion $\mathrm{D}$, related to population size or restricted range, was unusually frequent compared to other reptile assessments in the Mediterranean basin because these reptile taxa often occur on small islands and are sometimes even restricted to islets. However, if comparisons were limited to the assessments of other insular reptiles of that hotspot, criterion D would turn up more frequently (Pleguezuelos et al., 2002; Oliveira et al., 2005), as is the case for T. bischoffi from Selvagens (Madeira archipelago) and Gallotia bravoana from La Gomera (Canaries).

In Macaronesia Cape Verde may have the highest percentage of threatened taxa $(52 \%)$, followed by Madeira (50\%; Oliveira et al., 2005) and the Canary Islands (25\%; Pleguezuelos et al., 2002). Without considering the reptiles of Madeira, as it hosts a maximum of only five taxa, the high percentage of threatened taxa compared to the Canaries is alarming. It could be explained by the small total area of the Cape Verde archipelago (c. 50\% less than the Canary Islands), which restricts ranges of taxa, and by the increasing aridity that is affecting the islands, especially at lower altitudes (Langworthy \& Finan, 1997), which could have led to population reductions and extinctions. In the previous century cyclic droughts were caused by climate changes in Cape Verde but projections of rainfall changes for the region 


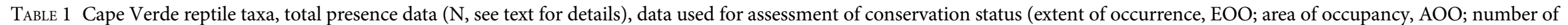

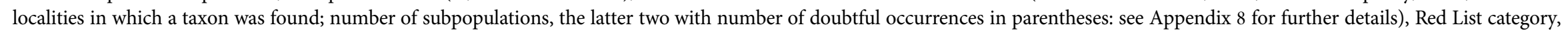
criteria used for Red List categorization (IUCN Standards and Petitions Subcommittee, 2010), and major threats (IUCN, 2010; Appendix 3).

\begin{tabular}{|c|c|c|c|c|c|c|c|c|}
\hline $\operatorname{Taxa}^{1}$ & $\mathrm{~N}^{2}$ & $\begin{array}{l}\mathrm{EOO}^{3} \\
\left(\mathrm{~km}^{2}\right)\end{array}$ & $\begin{array}{l}\mathrm{AOO}^{4} \\
\left(\mathrm{~km}^{2}\right)\end{array}$ & $\begin{array}{l}\text { No. of } \\
\text { localities }\end{array}$ & $\begin{array}{l}\text { No. of } \\
\text { subpopulations }\end{array}$ & $\begin{array}{l}\text { Red List } \\
\text { category }\end{array}$ & Criteria & Threats $^{6}$ \\
\hline \multicolumn{9}{|l|}{ Endemic species } \\
\hline Geochelone atlantica $\dagger$ López-Jurado et al. (1998) & NO & $?$ & 0 & 0 & $0(2)$ & $\mathrm{NE}$ & & \\
\hline \multicolumn{9}{|l|}{ Genus Hemidactylus Oken, 1817} \\
\hline H. bouvieri (Bocourt, 1870) & 34 & $?$ & 7 & $8(10)$ & $5(7)$ & $\mathrm{CR}$ & Blab(i,ii,iii,iv,v)c(iii,iv)+2ab(i,ii,iii,iv,v)c(iii,iv) & $1,2,7,9,12$ \\
\hline H. bouvieri bouvieri (Bocourt, 1870) & 7 & $?$ & $1^{*}$ & $2(4)^{*}$ & $2(4)$ & $\mathrm{CR}$ & B1ab(i,ii,iii,iv,v)c(iii) $+2 a b(i$, ii,iii,iv,v)c(iii); C1+2a(ii) & $1,2,7,9,12$ \\
\hline H. bouvieri ssp., São Nicolau & 5 & $?$ & $2^{*}$ & $2^{*}$ & 1 & $\mathrm{CR}$ & B1ab(i,ii,iii,iv,v)+2ab(i,ii,iii,iv,v); C1+2a(ii) & $1,2,7,9,12$ \\
\hline $\begin{array}{l}\text { H. bouvieri razoensis Gruber \& } \\
\text { Schleich (1982) }\end{array}$ & 22 & $?$ & $4^{*}$ & $4^{*}$ & 2 & $\mathrm{CR}$ & $\begin{array}{l}\text { B1ab(i,ii,iii,iv,v)c(i,ii,iii,iv)+2ab(i,ii,iii,iv,v)c(i,ii,iii,iv); } \\
\text { C1+2a(i,ii)b; D }\end{array}$ & $1,2,7,9,12$ \\
\hline H. boavistensis Boulenger (1906) & 91 & 723 & 47 & 14 & 4 & $\mathrm{LC}$ & & $1,2,7$ \\
\hline H. lopezjuradoi Arnold et al. (2008) & 3 & $?$ & $1^{*}$ & $1^{*}$ & 1 & $\mathrm{CR}$ & B1ab(i,ii,iii,iv,v)+2ab(i,ii,iii,iv,v); C1+2a(ii) & $1,2,7,9,12$ \\
\hline \multicolumn{9}{|l|}{ Genus Tarentola Gray, 1825} \\
\hline T. boavistensis Joger (1993) & 39 & 458 & 27 & 7 & 2 & $\mathrm{VU}$ & $\mathrm{C} 1 ; \mathrm{D} 1$ & 7,9 \\
\hline T. bocagei Vasconcelos et al. (2012) & 20 & 43 & $9^{*}$ & 7 & 1 & VU & D2 & 9 \\
\hline T. fogoensis Vasconcelos et al. (2012) & 44 & 341 & 20 & 8 & 1 & LC & & 7 \\
\hline T. darwini Joger (1984b) & 152 & 839 & 65 & 9 & 2 & LC & & 0 \\
\hline T. substituta Joger (1984b) & 160 & 151 & 45 & 8 & $1^{7}$ & $\mathrm{LC}$ & & 7 \\
\hline T. raziana Schleich (1984) & 84 & 28 & 22 & 8 & 3 & $\mathrm{VU}$ & $\mathrm{B} 1 \mathrm{ab}(\mathrm{v})+2 \mathrm{ab}(\mathrm{v}) ; \mathrm{C} 1$ & $1,2,7$ \\
\hline T. caboverdiana Schleich (1984) & 89 & 545 & 37 & 7 & 1 & LC & & 0 \\
\hline T. nicolauensis Schleich (1984) & 111 & 198 & 41 & 10 & $1^{7}$ & LC & & 0 \\
\hline T. gigas (Bocage, 1875) & 74 & $<10$ & $6^{*}$ & $4^{*}$ & 2 & EN & B1ac(iv)+2ac(iv) & $7,8,9,10$ \\
\hline T. gigas gigas (Bocage, 1875) & 39 & $<3$ & $3^{*}$ & $2^{*}$ & 1 & EN & B1ac(iv)+2ac(iv) & $7,8,9,10$ \\
\hline T. gigas brancoensis Schleich (1984) & 35 & $<6$ & $3^{*}$ & $2^{*}$ & 1 & EN & Blac(iv)+2ac(iv) & $7,8,9,10$ \\
\hline T. rudis Boulenger (1906) & 43 & 254 & 22 & 7 & 2 & $\mathrm{VU}$ & D1 & 8 \\
\hline T. protogigas Joger (1984b) & 75 & 75 & 22 & 11 & 4 & & & $7,9,12$ \\
\hline T. protogigas protogigas Joger (1984b) & 13 & 31 & $4^{*}$ & $3^{*}$ & 1 & $\mathrm{CR}$ & B1ab(i,ii,v)+2ab(i,ii,v); C2a(ii) & $7,9,12$ \\
\hline T. protogigas hartogi Joger (1993) & 62 & 45 & $18^{*}$ & 8 & 3 & VU & D2 & 7 \\
\hline T. maioensis Schleich (1984) & 57 & 195 & 22 & 6 & 1 & LC & & 7 \\
\hline \multicolumn{9}{|l|}{ Genus Chioninia (Gray, 1845) } \\
\hline C. vaillanti (Boulenger, 1887) & 43 & 446 & 20 & 11 & 3 & EN & D2 & 7,9 \\
\hline C. vaillanti vaillanti (Boulenger, 1887) & 19 & 317 & $12^{*}$ & $5^{*}$ & 1 & EN & $\mathrm{D} 1+2$ & 9 \\
\hline C. vaillanti xanthotis Miralles et al. (2010) & 24 & 129 & $8^{*}$ & 6 & 2 & EN & $\mathrm{D} 1+2$ & 7,9 \\
\hline C. delalandii (Duméril \& Bibron, 1839) & 341 & 1,134 & 141 & 37 & $7^{7}$ & LC & & 7 \\
\hline C. nicolauensis (Schleich, 1987) & 43 & 183 & 21 & 9 & 1 & LC & & 7 \\
\hline C. fogoensis (O’Shaughnessy, 1874) & 95 & 344 & 46 & 9 & 1 & $\mathrm{LC}$ & & 2 \\
\hline C. stangeri (Gray, 1845) & 122 & 101 & 28 & 23 & 4 & $\mathrm{EN}$ & B1ab(i,ii,iii,v)+2ab(i,ii,iii,v); C1+2a(ii) & 2,7 \\
\hline C. coctei (Duméril \& Bibron, 1839) & 49 & 6 & $7^{*}$ & $3^{*}$ & $3(5)$ & EX & & $1,2,3,7,9$ \\
\hline C. spinalis (Boulenger, 1906) & 297 & 2,035 & 129 & 34 & 9 & LC & & $0,7,9$ \\
\hline C. spinalis salensis (Angel, 1935) & 39 & 142 & $17^{*}$ & 6 & 1 & VU & D2 & 7,9 \\
\hline C. spinalis santiagoensis Miralles et al. (2010) & 67 & 790 & 31 & 6 & 3 & LC & & 0 \\
\hline C. spinalis spinalis (Boulenger, 1906) & 37 & 295 & $14^{8}$ & 8 & 1 & LC & & 7 \\
\hline
\end{tabular}




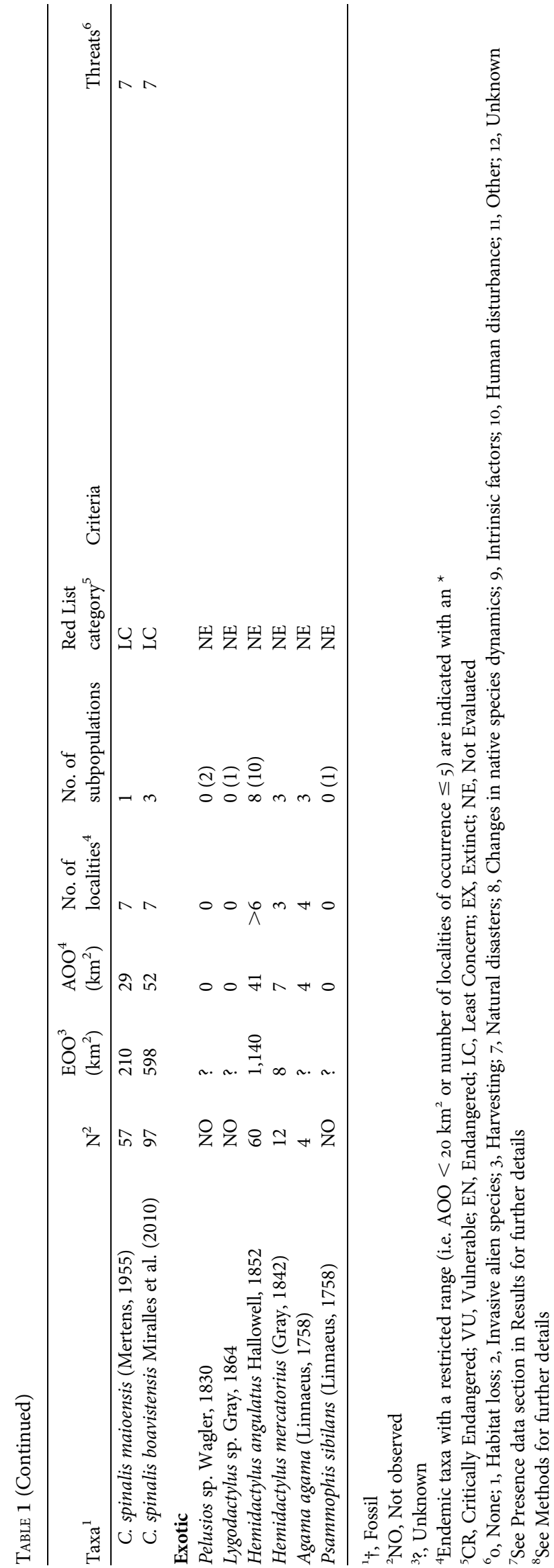

in response to global warming are highly uncertain (Biasutti et al., 2008). If droughts become more pronounced this could compromise the viability of some reptile populations, and thus increased conservation efforts are needed to ensure a secure future for the herpetofauna of Cape Verde.

National laws to protect all threatened taxa are needed as current legislation is inadequate in the face of recent taxonomic changes and new distribution data. In addition, education campaigns are required to increase awareness and capacity-building so that Cape Verdeans can protect the endemic reptiles of the archipelago better. Particular attention should be paid to new legislation to protect H. bouvieri, H. lopezjuradoi and T. p. protogigas, which have restricted AOO, are Critically Endangered and for which there are few records. Management plans are required to prevent the extinction of these taxa. Research and policybased action, accompanied by species-based actions, such as control and eradication of invasive and potential competing species, are imperative to ensure the viability of the endemic Hemidactylus. This also applies to the subspecies of T. gigas, for which improved annual estimates of the abundance of mature individuals are needed because demographic fluctuations are likely to occur within their extremely restricted ranges (both occur on small islets) as a result of cyclic droughts and variation in the numbers of birds with which both subspecies have trophic relationships. The Endangered C. vaillanti also requires a management plan as its range has probably already been reduced by increasing aridity, as suggested by the finding of subfossil records on Boavista and Maio, where the species is no longer found (Carranza et al., 2001). In addition, C. stangeri on São Vicente deserves particular attention because of its small range. Removal of introduced mammals from Santa Luzia is needed to conserve the threatened C. stangeri and T. raziana.

Currently, only four of the 46 terrestrial protected areas on Cape Verde have been legally gazetted, and it is important to guarantee that protected areas will encompass all reptile taxa and evolutionarily significant units (Miralles et al., 2010; Vasconcelos et al., 2010). At present this is not the case because, for example, there are no protected areas planned for Brava, where the largest population of T. p. hartogi occurs. The opportunity to optimize the design and location of such areas for reptiles needs to be taken, following the recommendations of Vasconcelos et al. (2012a).

In general little is known about the biology and demography of the threatened reptiles of Cape Verde; further ecological studies and quantification of the major threats affecting these taxa are required. The new data on distribution and conservation status presented here may improve the options for assessing conservation priorities for this group. The findings of this research will be passed to the Cape Verde governmental authorities, which have shown 
great interest in this work and, considering their budgetary constraints, have provided considerable assistance and support. Ultimately, the effective protection of the biodiversity of Cape Verde is dependent on the necessary funds becoming available to support the implementation and management of the protected area network and future conservation action plans.

\section{Acknowledgements}

RV is grateful to S. Rocha, M. Fonseca and A. Perera from Centro de Investigação em Biodiversidade e Recursos Genéticos, S. Martins, J. Motta, H. Abella and A. Nevsky for help during fieldwork, R. Freitas, J. César, Dr Domingos, Eng. Orlando, J. Gonçalves, L. Carvalho, C. Dias, I. Gomes and staff from the former Ministério do Ambiente Agricultura e Pescas and Instituto Nacional de Investigação e Desenvolvimento Agrário for logistical aid, and J. Roca for lab assistance. Research was supported by Fundação para a Ciência e Tecnologia (FCT) (SFRH/BD/ 25012/2005 and SFRH/BPD/79913/2011, to RV), PTDC/BIA$\mathrm{BDE} / 74288 / 2006$. JCB and DJH have contracts with FCT (Programa Ciência 2007/2008 Fundo Social Europeu) and Ministerio de Educación y Ciencia, Spain (CGL2009-11663/ BOS). Samples were obtained under licence 07/2008 from the Direcção Geral do Ambiente, Cape Verdean Government.

\section{References}

AKCAKaya, H.R. \& Ferson, S. (2001) RAMAS ${ }^{\circ}$ Red List: Threatened Species Classifications under Uncertainty. Version 2.o. Applied Biomathematics, Setauket, USA.

Andreone, F. (2000) Herpetological observations on Cape Verde: a tribute to the Italian naturalist Leonardo Fea, with complementary notes on Macroscincus coctei (Duméril \& Bibron, 1839) (Squamata: Scincidae). Herpetozoa, 13, 15-26.

Andreone, F. \& Guarino, F.M. (2003) Giant or long-lived? Age structure in Macroscincus coctei, an extinct skink from Cape Verde. Amphibia-Reptilia, 24, 459-470.

Angel, F. (1935) Lézards des Îles du Cap Vert, rapportés par M. le Professeur Chevalier. Description de espèces nouvelles. Bulletin $d u$ Muséum d'Histoire Naturelle, Paris, 2, 165-169.

ANGEL, F. (1937) Sur la faune herpétologique de l'Archipel du Cap Vert. XII. Congrès International Zoologie, Lisbonne, 1935, 1693-1700.

Anonymous (2002) Boletim Oficial da Républica de Cabo Verde 2002. Artigo no. 37. Ministério da Justiça, Praia, Cape Verde.

Arnold, E.N., Vasconcelos, R., Harris, D.J., Mateo, J.A. \& Carranza, S. (2008) Systematics, biogeography and evolution of the endemic Hemidactylus geckos (Reptilia, Squamata, Gekkonidae) of the Cape Verde Islands based on morphology and mitochondrial and nuclear DNA sequences. Zoologica Scripta, 37, 619-636.

Beyer, H.L. (2004) Hawth's Analysis Tools for ArcGIS. Http://www. spatialecology.com/htools [accessed 10 January 2010].

Biasutti, M., Held, I.M., Sobel, A.H. \& Giannini, A. (2008) SST forcings and Sahel rainfall variability in simulations of the twentieth and twenty-first centuries. Journal of Climate, 21, 3471-3486.
Bocage, J.V. (1873) Melanges ertologiques. II. Sur quelques reptiles et batraciens nouveaux rares ou peu connus d'Afrique occident. Jornal de Sciencias Mathematicas, Physicas e Naturaes, Academia Real das Sciencias de Lisboa, 4, 209-227.

Bocage, J.V. (1875) Sur deux reptiles nouveaux de l'Archipel du Cap-Vert. Jornal de Sciencias Mathematicas, Physicas e Naturaes, Academia Real das Sciencias de Lisboa, 5, 287-290.

Bocage, J.V. (1896) Reptis de algumas possessões portuguezas d'Africa que existem no museu de Lisboa. Jornal de Sciencias Mathematicas, Physicas e Naturaes, Segunda Série, IV, 65-104, estampas I e II.

Bocage, J.V. (1897) Mammiferos, repteis e batrachios d'Africa de que existem exemplares typicos no Museu de Lisboa. Jornal de Sciencias Mathematicas, Physicas e Naturaes, Academia Real das Sciencias de Lisboa, 4, 187-206.

Bocage, J.V. (1902) Aves e reptis de Cabo Verde. Jornal de Sciencias Mathematicas, Physicas e Naturaes, Academia Real das Sciencias de Lisboa, 14, 206-210.

Bocourt, F. (1870) Description des quelques sauriens nouvaux originaires de l'Amerique meridionale. Archives du Muséum d'Histoire Naturelle, Paris, 6, 11-18.

Boulenger, G.A. (1885) Catalogue of the lizards in the British Museum (Natural History), Volume I, and edition. Trustees of the British Museum, Taylor and Francis, London, UK.

Boulenger, G.A. (1887) Catalogue of the lizards in the British Museum (Natural History), Volume III, 2nd edition. Trustees of the British Museum, Taylor and Francis, London, UK.

Boulenger, G.A. (1906) Report on the reptiles collected by the late L. Fea in West Africa. Annali del Museo Civico di Storia Naturale di Genova, 3, 196-216.

Brehm, A., Jesus, J., Pinheiro, M. \& Harris, D.J. (2001) Relationships of scincid lizards Mabuya (Reptilia: Scincidae) from the Cape Verde Islands based on mitochondrial and nuclear DNA sequences. Molecular Phylogenetics and Evolution, $19,311-316$.

Brown, R.P., Suarez, N.M., Smith, A. \& Pestano, J. (2001) Phylogeography of Cape Verde Islands skinks (Mabuya). Molecular Ecology, 10, 1593-1597.

BRYgoo, É. (1985) Les types de Scincidés (Reptiles, Sauriens) du Muséum National d'Histoire Naturelle. Catalogue critique. Bulletin du Muséum National d'Histoire Naturelle (serie 4), 7, 1-126.

Brygoo, É. (1990) Les types de Gekkonidés (Reptiles, Sauriens) du Muséum National d'Histoire Naturelle. Catalogue critique. Bulletin du Muséum National d'Histoire Naturelle (serie 4), 12, 19-141.

Carranza, S. \& ARnold, E.N. (2003) Investigating the origin of transoceanic distributions: mtDNA shows Mabuya lizards (Reptilia, Scincidae) crossed the Atlantic twice. Systematics and Biodiversity, 1 , $275-282$.

Carranza, S. \& Arnold, E.N. (2006) Systematics, biogeography, and evolution of Hemidactylus geckos (Reptilia: Gekkonidae) elucidated using mitochondrial DNA sequences. Molecular Phylogenetics and Evolution, 38, 531-545.

Carranza, S., Arnold, E.N., Mateo, J.A. \& Geniez, P. (2002) Relationships and evolution of the North African geckos, Geckonia and Tarentola (Reptilia: Gekkonidae), based on mitochondrial and nuclear DNA sequences. Molecular Phylogenetics and Evolution, 23, 244-256.

Carranza, S., Arnold, E.N., Mateo, J.A. \& López-Jurado, L.F. (2000) Long-distance colonization and radiation in gekkonid lizards, Tarentola (Reptilia: Gekkonidae), revealed by mitochondrial DNA sequences. Proceedings of the Royal Society of London Series B, 267, 637-649.

Carranza, S., Arnold, E.N., Mateo, J.A. \& López-Jurado, L.F. (2001) Parallel gigantism and complex colonization patterns in the 
Cape Verde scincid lizards Mabuya and Macroscincus (Reptilia: Scincidae) revealed by mitochondrial DNA sequences. Proceedings of the Royal Society of London Series B, 268, 1595-1603.

Case, T.J., Bolger, D.T. \& Richman, A.D. (1992) Reptilian extinctions: the last ten thousand years. In Conservation Biology: The Theory and Practice of Conservation, Preservation, and Management (eds P.L. Fiedler \& S.K. Jain), pp. 91-125. Chapman \& Hall, New York, USA.

Chadwick, E. \& Slater, F. (2005) A population of skinks (Mabuya spp.) and the gecko Hemidactylus bouvieri boavistensis behind coastal dunes on Boa Vista, Cape Verde Islands. Herpetological Bulletin, 92, 14-18.

Chevalier, A. (1935) Les îles du Cape Vert: géographie, agriculture, flore de l'archipel. Revue de Botanique Appliquée et d'Agriculture Tropicale, 15, 733-1090.

Clarke, T. (2006) Field Guide to the Birds of the Atlantic Islands. Christopher Helm, London, UK.

Cole, N.C., Jones, C.G. \& Harris, S. (2005) The need for enemy-free space: the impact of an invasive gecko on island endemics. Biological Conservation, 125, 467-474.

Dekeyser, P.L. \& Villiers, A. (1951) Mission J. Cadenet aux Iles du Cap Vert. Bulletin de L'Institute français d'Afrique noire, 13, $1152-1158$.

Dinız, A.C. \& Matos, G.C. (1986) Carta de Zonação Agro-Ecológica e da Vegetação de Cabo Verde I-Ilha de Santiago. Garcia da Horta, Série de Botânica, Instituto de Investigação Científica Tropical, 8, 39-82.

Diniz, A.C. \& Matos, G.C. (1987) Carta de Zonação Agro-Ecológica e da Vegetação de Cabo Verde II-Ilha do Fogo. Garcia da Horta, Série de Botânica, Instituto de Investigação Científica Tropical, 9, 35-69.

DınıZ, A.C. \& Matos, G.C. (1988a) Carta de Zonação Agro-Ecológica e da Vegetação de Cabo Verde III-Ilha do Maio. Garcia da Horta, Série de Botânica, Instituto de Investigação Científica Tropical, 10, $19-48$.

Diniz, A.C. \& Matos, G.C. (1988b) Carta de Zonação Agro-Ecológica e da Vegetação de Cabo Verde IV-Ilha da Boavista. Garcia da Horta, Série de Botânica, Instituto de Investigação Científica Tropical, 10, 49-72.

Diniz, A.C. \& Matos, G.C. (1993) Carta de Zonação Agro-Ecológica e da Vegetação de Cabo Verde V-Ilha do Sal. Garcia da Horta, Série de Botânica, Instituto de Investigação Científica Tropical, 11, 9-30.

Diniz, A.C. \& Matos, G.C. (1994) Carta de Zonação Agro-Ecológica e da Vegetação de Cabo Verde VI e VII-Ilha de S. Vicente-Ilha Sta. Luzia. Garcia da Horta, Série de Botânica, Instituto de Investigação Científica Tropical, 12, 69-100.

Diniz, A.C. \& Matos, G.C. (1999a) Carta de Zonação Agro-Ecológica e da Vegetação de Cabo Verde VIII-Ilha de S. Nicolau. Garcia da Horta, Série de Botânica, Instituto de Investigação Científica Tropical, 14, 1-54.

Diniz, A.C. \& MAtos, G.C. (1999b) Carta de Zonação Agro-Ecológica e da Vegetação de Cabo Verde IX-Ilha Brava. Garcia da Horta, Série de Botânica, Instituto de Investigação Científica Tropical, 14, 55-82.

Diniz, A.C. \& MAtos, G.C. (1999c) Carta de Zonação Agro-Ecológica e da Vegetação de Cabo Verde X-Ilha de Santo Antão. Garcia da Horta, Série de Botânica, Instituto de Investigação Científica Tropical, 14, 1-34.

Duarte, M.C. \& Romeiras, M.M. (2009) Cape Verde Islands. In Encyclopedias of Islands (eds R.G. Gillespie \& D.A. Clague), pp. 143-148. University of California Press, Berkeley, USA.

Duméril, A.M.C. \& Bibron, G. (1839) Erpétologie générale ou Histoire naturelle complète des Reptiles. Tome V. Librairie Encyclopédique de Roret, Paris, France.

Duprat, H.I., Friis, J., Holm, P.M., Grandvuinet, T. \& Sørensen, R.V. (2007) The volcanic and geochemical development of São Nicolau, Cape Verde Islands: constraints from field and 40Ar/39Ar evidence. Journal of Volcanology and Geothermal Research, 162, 1-19.

Frankham, R. (1997) Do island populations have less genetic variation than mainland populations? Heredity, $78,311-327$.

Frazen, M. \& Glaw, F. (2007) Type catalogue of reptiles in the Zoologische Staatssammlung München. Spixiana, 30, 201-276.

GonzÁlez, M.E. \& López-Jurado, L.F. (2004) Referencia de experto. Cambios taxonómicos y corológicos de reptiles y mamíferos. Justificación de sinonimias de vertebrados. In Banco de Datos de Biodiversidad de Cabo Verde-Archivo Documental. Unpublished Report. Atlántico Cabo Verde (PELCRIN Voooo8)-INTERREG IIIB.

Gray, J.E. (1845) Catalogue of the Specimens of Lizards in the Collection of the British Museum. Edward Newman Trustees of the British Museum, London, UK.

Greer, A.E. (1976) On the evolution of the giant Cape Verde scincid lizard Macroscincus coctei. Journal of Natural History, 10, 691-712.

Gruber, H.J. \& Schleich, H.-H. (1982) Hemidactylus bouvieri razoensis nov. ssp. von den Kapverdischen Inseln (Reptilia: SauriaGekkonidae). Spixiana, 5, 303-310.

Hazevoet, C.J. (1995) The Birds of the Cape Verde Islands. B.O.U. Check-list no. 13. British Ornithologists' Union, Tring, UK.

Hijmans, R.J., Cameron, S.E., Parra, J.L., Jones, P.G. \& Jarvis, A. (2005) Very high resolution interpolated climate surfaces for global land areas. International Journal of Climatology, 25, 1965-1978. Http://www.worldclim.org [accessed 1 March 2010].

IUCN (2010) The Habitats Authority File and the Threats Type Authority File. Http://www.iucn.org/about/work/programmes/ species/red_list/resources/technical_documents/authority_files/ [accessed 10 January 2010].

iUCN Standards and Petitions Subcommittee (2010) Guidelines for Using the IUCN Red List Categories and Criteria: Version 8.o. IUCN, Gland, Switzerland. Http://intranet.iucn.org/ webfiles/doc/SSC/RedList/RedListGuidelines.pdf [accessed 10 January 2010].

Jesus, J., Brehm, A. \& Harris, D.J. (2002) Relationships of Tarentola (Reptilia: Gekkonidae) from the Cape Verde islands estimated from DNA sequence data. Amphibia-Reptilia, 22, 235-242.

Jesus, J., Brehm, A. \& Harris, D.J. (2005) Phylogenetic relationships of Hemidactylus geckos from the Gulf of Guinea islands: patterns of natural colonizations and anthropogenic introductions estimated from mitochondrial and nuclear DNA sequences. Molecular Phylogenetics and Evolution, 34, 480-485.

Jesus, J., Brehm, A., Pinheiro, M. \& Harris, D.J. (2001) Relationships of Hemidactylus (Reptilia: Gekkonidae) from the Cape Verde Islands: what mitochondrial DNA data indicate. Journal of Herpetology, 35, 672-675.

Joger, U. (1984a) Taxonomische revision der gattung Tarentola (Reptilia, Gekkonidae). Bonner zoologische Beiträge, 35, 129-174.

Joger, U. (1984b) Die Radiation der gattung Tarentola in Makaronesien (Reptilia: Sauria: Gekkonidae). Courier Forschungsinstitut Senckenberg, 71, 91-111.

JogER, U. (1993) On two collections of reptiles and amphibians from the Cape Verde Islands, with descriptions of three new taxa. Courier Forschungsinstitut Senckenberg, 159, 437-444.

Kier, G., Kreft, H., Lee, T.M., Jetz, W., Ibisch, P.L., Nowicki, C. et al. (2009) A global assessment of endemism and species richness across island and mainland regions. Proceedings of the National Academy of Sciences of the USA, 106, 9322-9327.

Köhler, J. \& Gústen, R. (2007) Herpetological type specimens in the natural history collections of the museums in Darmstadt and Wiesbaden, Germany. Spixiana, 30, 275-288. 
Köhler, G., Hertz, A., Sunyer, J. \& Monteiro, A. (2007a) Geographic distribution. Hemidactylus bouvieri. Herpetological Review, 38, 483.

Köhler, G., Hertz, A., Sunyer, J., Seipp, R. \& Monteiro, A. (2007b) Herpetologische forschungen auf den Kapverden unter besonderer berücksichtigung des Kapverdischen Riesenskinks, Macroscincus coctei. Elaphe, 15, 75-79.

LANG Worthy, M. \& Finan, T.J. (1997) Waiting for Rain-Agriculture and Ecological Imbalance in Cape Verde. Lynne Rienner Publishers, Boulder, USA.

Leyens, T. \& Lobin, W. (eds) (1996) Primeira Lista Vermelha de Cabo Verde. Courier Forschungsinstitut Senckenber, Frankfurt, Germany.

López-Jurado, L.F., Mateo, J.A. \& Fazeres, A.I. (2005) Chordata. In Lista Preliminar de Espécies Silvestres de Cabo Verde. Hongos, Plantas Y Animales Terrestres (eds M. Arechavaleta, N. Zurita, M.C. Marrero \& J.L. Martín), p. 101. Gobierno de Canárias, Consejería de Médio Ambiente, Canary Islands.

López-Jurado, L.F., Mateo, J.A. \& García-Marquez, M. (1998) La tortuga fósil de la isla de Sal (Archipiélago de Cabo Verde). Revista Española de Herpetologia, 12, 111-114.

López-Jurado, L.F., Mateo, J.A. \& Geniez, P. (1999) Los Reptiles de La Isla de Boavista (Archipiélago de Cabo Verde). Boletín de la Asociación Herpetológica Española, 10, 10-13.

Loveridge, A. (1947) Revision of the African lizards of the family Gekkonidae. Bulletin of the Museum of Comparative Zoology at Harvard College, 98, 3-469.

MAAP-DGA (Ministério do Ambiente Agricultura e Pescas-Direcção Geral do Ambiente) (ed.) (2004) Livro Branco sobre o Estado do Ambiente em Cabo Verde. Praia, Santiago, Cape Verde.

Mateo, J.A., García-Márquez, M., López-Jurado, L.F. \& Pether, J. (1997) Nuevas observaciones herpetológicas en las Islas Desertas (Archipelago de Cabo Verde). Boletín de la Asociación Herpetológica Española, 8, 8-11.

Mateo, J.A., López-Jurado, L.F. \& García-Márquez, M. (2005) Primeras evidencias de la supervivencia del Escinco Gigante de Cabo Verde Macroscincus coctei (Duméril \& Bibron, 1839). Boletín de la Asociación Herpetológica Española, $15,73-75$.

Mateo, J.A., López-Jurado, L.F. \& Géniez, P. (2009) Historical distribution of Razo lark Alauda razae in the Cape Verde archipelago. Alauda, 77, 309-312.

Mertens, R. (1955) Die Eidechsen des Kapverden. Societas Scientiarum Fennica. Commentationes Biologicae, 15, 1-17.

Miralles, A., Vasconcelos, R., Harris, D.J., Perera, A. \& Carranza, S. (2010) An integrative taxonomic revision of the Cape Verdean skinks (Squamata, Scincidae). Zoologica Scripta, 40, 16-44.

Naurois, R. (1994) Les Oiseaux de L'archipel du Cap Vert. As aves do Arquipélago de Cabo Verde. Instituto de Investigação Científica Tropical, Lisboa, Portugal.

Oliveira, M.E. (coord.), Brito, J.C., Delinguer, T., Ferrand de Almeida, N., Loureiro, A., Martins, H.R. et al. (2005) Répteis. In Livro Vermelho dos Vertebrados de Portugal (eds J. Almeida, P.R. Almada, T. Dellinger, N. Ferrand de Almeida, M.E. Oliveira, J.M. Palmeirim et al.), pp. 125-144. Instituto de Conservação da Natureza, Lisboa, Portugal.

Orlandi, S. (1894) Note anatomiche sul Macroscincus coctei (Barb. du Boc.). Atti della Società Linguistica di Scienze Naturali e Geografiche, Genova, 5, 175-204.

O'Shaughnessy, A.W.E. (1874) Descriptions of new species of Scincidae in the collection of the British Museum. The Annals and Magazine of the Natural History, 4, 298-301.
Paiva, J. (ed.) (1995) Flora de Cabo Verde. Plantas Vasculares. Instituto de Investigação Científica Tropical, and Instituto Nacional de Investigação e Desenvolvimento Agrário, Lisboa, Portugal and Praia, Cape Verde.

Peracca, M.G. (1891) Sulla oviparità del Macroscincus coctaei Dum. c Bibr.. Bollettino dei Musei di Zoologia ed Anatomia comparata della R. Università di Torino, 6, 1-5.

Pinheiro, M. (1990) Mabuya fogoensis O' Shaughnessy (Sauria, Scincidae) e Mabuya stangeri (Gray) de algumas ilhas do arquipélago de Cabo Verde. Garcia de Horta, Série Zoológica, 15 , 49-56.

Pleguezuelos, J.M., Brito, J.C., Fahd, S., Feriche, M., Mateo, J. A., Moreno-Rueda, G. et al. (2010) Setting conservation priorities for the Moroccan herpetofauna: the utility of regional red listing. Oryx, 44, 501-508.

Pleguezuelos, J.M., Márquez, R. \& Lizana, M. (2002) Atlas y libro rojo de los anfíbios y reptiles de España. Dirección General de Conservación de la Naturaleza, Asociación Herpetologica Española, Madrid, Spain.

Pullin, A.S. (2002) Conservation Biology. Cambridge University Press, Cambridge, UK.

Schleich, H.-H. (1980) Der kapverdische Riesengecko, Tarentola delalandii gigas (Bocage, 1896). Spixiana, 3, 147-155.

Schleich, H.-H. (1982a) Letze nachforschungen zum Kapverdischen Riesenskinks, Macroscincus coctei (Duméril \& Bibron 1839) (Reptilia: Sauria: Scincidae). Salamandra, 18, 78-85.

SCHLEICH, H.-H. (1982b) Vorlaufige mitteilung zur herpetofauna der Kapverden. Courier Forschunginstitut Senckenberg, 52, 245-248.

Schleich, H.-H. (1984) Die geckos der gattung Tarentola der Kapverden (Reptilia: Sauria: Gekkonidae). Courier Forschungsinstitut Senckenberg, 71, 95-106.

Schleich, H.-H. (1987) Herpetofauna Caboverdiana. Spixiana, 12 , $1-75$.

Schleich, H.-H. (1996) Lista Vermelha para os Répteis (Reptilia). In Primeira Lista Vermelha de Cabo Verde (eds T. Leyens \& W. Lobin), pp. 122-125. Courier Forschungsinstitut Senckenberg, 193, Frankfurt, Germany.

Schleich, H.-H. \& Wut ke, M. (1983) Die Kapverdishe eilande Santa Luzia, Branco und Razo - ein reisebericht. Natur und Museum 113, 33-45.

Serpa-Pinto (1896) Carta de Serpa Pinto a Bocage de 6 Fevereiro de 1896. Arquivo Histórico de Correspondência Nacional do Museu Bocage CN/P-23, Lisboa, Portugal.

Torres, P.C., Silva, L.C., Serralheiro, A., Tassinari, C. \& Munhá, J. (2002) Enquadramento geocronológico pelo método K/Ar das principais sequências vulcano-estratigráficas da ilha do Sal-CaboVerde. Garcia de Orta, Série Geológica, 18, 9-13.

Vaillant, M.L. (1882) Sur les Macroscincus coctei, D., B., récemment arrivés à la ménagerie du Muséum d'Histoire Naturelle. Comptes Rendus hebdomadaires des Séances de L'Académie des Sciences, 94, 811-812.

Vasconcelos, R., Brito, J.C., Carvalho, S., Carranza, S. \& HARRIS, D.J. (2012a) Identifying priority areas for island endemics using genetic versus specific diversity-the case of the terrestrial reptiles of the Cape Verde Islands. Biological Conservation, 153, 276-286.

Vasconcelos, R., Carranza, S. \& Harris, D.J. (2010) Insight into an island radiation: the Tarentola geckos of the Cape Verde archipelago. Journal of Biogeography, 37, 1047-1060.

Vasconcelos, R., Perera, A., Geniéz, P., Carranza, S. \& HARRIS, D.J. (2012b) An integrative taxonomic revision of the Tarentola geckos (Squamata, Phyllodactylidae) of the Cape 
Verde Islands. Zoological Journal of the Linnean Society, 164, 328-360.

Vasconcelos, R., Rocha, S., Brito, J.C., Harris, D.J. \& Carranza, S. (2009) First report of introduced African rainbow lizard Agama agama (Linnaeus, 1758) in the Cape Verde Islands. Herpetozoa, 21, 183-186.

\section{Appendices 1-9}

The appendices for this article are available online at http:/ journals.cambridge.org

\section{Biographical sketches}

Raquel Vasconcelos studied the herpetofauna of the Cape Verde Islands, combining geographical information systems and molecular tools, and is now studying the reptiles of the Socotra archipelago. José CARLOS BRITO is interested in geographical patterns of biodiversity and is the principal investigator of the BIODESERTS (Biodiversity of Deserts and Arid Regions) group. S A LVA D OR CARRANZA has a longstanding interest in the herpetofauna of the Mediterranean Basin, Old World deserts and oceanic islands. D. JAMES HARRIS is interested in phylogenetics, especially of reptiles, and leads several projects on the genetic and morphological variation of reptiles of the Mediterranean Basin and other areas. 